Article

\title{
Impact of Construction Project Managers' Emotional Intelligence on Project Success
}

\author{
Alessandra Montenegro ${ }^{1, *}$, Marina Dobrota ${ }^{2} \mathbb{D}$, Marija Todorovic ${ }^{2}$, Teodora Slavinski ${ }^{2}(\mathbb{D}$ \\ and Vladimir Obradovic ${ }^{2}$ (D) \\ 1 Saga New Frontier Group, GTC House, Bulevar Zorana Đinđića 64a, 11070 Belgrade, Serbia \\ 2 Faculty of Organizational Sciences, University of Belgrade, 11000 Belgrade, Serbia; \\ marina.dobrota@fon.bg.ac.rs (M.D.); todorovicm@fon.bg.ac.rs (M.T.); teodora.slavinski@fon.bg.ac.rs (T.S.); \\ obradovicv@fon.bg.ac.rs (V.O.) \\ * Correspondence: alessandra.montenegro@saga.rs; Tel.: +381-60-6077075
}

Citation: Montenegro, A.; Dobrota, M.; Todorovic, M.; Slavinski, T.; Obradovic, V. Impact of Construction Project Managers' Emotional Intelligence on Project Success. Sustainability 2021, 13, 10804. https://doi.org/10.3390/su131910804

Academic Editors: Mladen Vukomanovic and Michał Juszczyk

Received: 1 August 2021

Accepted: 9 September 2021

Published: 28 September 2021

Publisher's Note: MDPI stays neutral with regard to jurisdictional claims in published maps and institutional affiliations.

Copyright: (c) 2021 by the authors. Licensee MDPI, Basel, Switzerland. This article is an open access article distributed under the terms and conditions of the Creative Commons Attribution (CC BY) license (https:/ / creativecommons.org/licenses/by/ $4.0 /)$.

\begin{abstract}
Numerous authors are persistent in investigating the competency profile of the ideal construction project manager in order to decrease the failure rate of construction projects. There is evidence for the change in construction project management, from traditional practices to practices more focused on people and working relationships. The literature demonstrates a positive correlation between project manager's Emotional intelligence and project success but less is written about the mechanisms that interfere with that relationship. Furthermore, project manager's relationships with stakeholders are recognized as an important determinant of project success in the construction industry. Considering the above facts, this study was motivated to examine how the construction project manager's emotional intelligence influences project success, and whether the relations with internal and external stakeholders interfere as mediators in that relationship. In the conducted research, 110 project managers participated. The results demonstrate that the emotional intelligence of construction project managers significantly influences the project success and that internal and external stakeholder relationships play an important role as mediators among them. Moreover, it is found that some components of EI have more significant influence on stakeholder relationships and project success and that internal and external relationships in different amounts affect components of project success.
\end{abstract}

Keywords: construction project manager; emotional intelligence; project success; internal and external stakeholder relationships

\section{Introduction}

The construction industry, as one of the most complex project-based industrial sectors, is in the focus of project management researchers for years. The authors are persistent in investigating the project manager's competencies in order to find the competency profile of the ideal project manager working in this industry [1,2]. The reason lies in the fact that an increasing number of projects in the construction industry have failed due to poor project management [3,4]. For a long time, technical competencies were considered the most important characteristics of a successful construction project manager, while social competencies were neglected. Recent studies emphasize that emotional intelligence improves managing projects and lead to successful project realization [5-8]. Thus, there is evidence for the change in construction from traditional project management that concentrates on planning and control to new project management that highlights the importance of people and working relationships $[1,5]$.

Although a multitude of studies demonstrated positive correlation between project manager's emotional intelligence and project success, only a few of them explained the mechanisms that interfere among them. Rezvani et al. [9] examined the mediating effects of project managers' job satisfaction and trust on the relationships between EI and project 
success. He concluded that job satisfaction and trust lead to better project performance in complex conditions. Leadership styles also mediate the relationship between emotional intelligence and collaboration satisfaction [10]. Lopes [11] figured out that transformational leadership is a mediator between EI and leader effectiveness, team effectiveness, and service climate. Mazur et al. [12] emphasize that internal and external stakeholder relationships and project managers' personality are very significant mediators between EI and project success.

The Mazur study motivated the authors of this paper to examine these relationships but with an emphasis on the construction industry. The justification for investigating the construction industry is because construction projects tend to have many stakeholders, and maintaining harmonized relationships with them might influence project success. Therefore, the research question was how the construction project manager's emotional intelligence influences project success, and whether the relations with internal and external stakeholders interfere as mediators in that relationship. The following section presents the theoretical background of the research. Furthermore, Section 3 explains the research model and hypotheses development while Section 4 describes the research methodology. The results are presented in Section 5. Finally, in the last chapter space was left for discussion, limitations, and future research direction.

\section{Theoretical Background}

Considering that this research investigates the impact of construction project managers' emotional intelligence on project success and stakeholder relationships as the mediating role in that relation, the following chapter presents the theoretical background of these concepts.

\subsection{Emotional Intelligence}

Emotional intelligence (EI) and its positive impact on employee performance, interpersonal relationships and overall project performance is an important topic in the project management literature [9,13-15]. For the first time, the term "Emotional Intelligence (EI)" was used in Salovey and Mayer's [16] work as "the ability to monitor one's own and others' feelings and emotions, to differentiate among them, and to use this information to guide one's thinking and actions". Maybe the most commonly adopted theoretical model of EI is Salovey and Mayer's "Four-Branch" model [16-18]. This model proposes the four fundamental emotion-related abilities: (1) perceiving emotions, (2) facilitating thought using emotion, (3) understanding emotions, and (4) managing emotions. Goleman [19] was a pioneer in introducing EI application in the work environment, and from that moment numerous research evidenced that an executive with good interpersonal and social skills can achieve better relationships with colleagues, superiors, and subordinates which leads to better work performance and overall business success [9,20-26]. Additionally, a manager with a higher EI coefficient is much more skillful in leadership [15,27] and team effectiveness [28]. Many authors emphasize that emotional intelligence has a crucial role in the effective management of complex projects $[21,23,29]$ and that soft skills are significant for construction project delivery [30]. The project manager's soft skills of understanding behavioral characteristics, leading, and influencing others became more important in the digital age than technical/hard skills [31].

The positive correlation between emotional intelligence and project success has been known for a long time, but less is known about the mechanism that interferes in that relationship. Studies on that subject have emerged recently [9,12,32,33]. Mazur [12] developed a model with internal and external stakeholder relationships as mediators between emotional intelligence and project success. The model was confirmed in the Australian Defense industry and the results showed that EI significantly affects the development, quality, and effectiveness of the relationships between project managers and their internal and external stakeholders and affects overall project success. However, the mentioned research does not consider these relationships in the context of the construction industry. Due to the above, this study aims to examine the relationship between project managers' emotional intelli- 
gence, project success, and their mediators (internal and external stakeholder relationships) in the construction industry.

\subsection{Project Success}

Although project management practitioners have made huge efforts to improve project success in construction, unsuccessful project realization is a very common occurrence in the digital era [34]. Project success has been a hot topic of project management studies for decades. As Müller and Jugdev [35] assert in their paper, in 1995 there were only two streams of research in the project management field: (1) optimization school—focused on technical aspects in managing projects (WBS and network planning techniques) and (2) project success school-researching factors on project success. Although the number of project management research streams has increased in the last two decades [22,36], interest for the project success has remained till now [37-40]. As Pinto points out, the main reason why this topic is widely represented in the literature is: "There are few topics in the field of project management that are so frequently discussed and yet so rarely agreed upon as that of the notion of project success" [41]. The definition of project success varies from author to author, but it is necessary to distinguish some commonly used terms. Project management scholars [35,42-44] differentiate two components of project success: (1) project success factors and (2) project success criteria. The first one relies on project elements that, if influenced, increase the probability of project success. According to the Oxford Dictionary [45], a criterion is defined as a standard of judgment or principle by which something is measured for value. This indicates that project success criteria are measures used for the assessment of whether the project was successful or not [35]. Additionally, there is a difference between project success and project management success [40]. The most common project management objective time/cost/quality triangle (called often iron triangle, the triple constraint) dominated as project success measurement from the 1960s to 1980s [40,46]. To differentiate the adduced terms, Table 1 represents historical project management success/project success trends.

Table 1. Historical project management success/project success trends.

\begin{tabular}{cccc}
\hline Research Focus & $\begin{array}{c}\text { Period 1 } \\
\text { 1960s-1980s }\end{array}$ & $\begin{array}{c}\text { Period 2 } \\
\text { 1980s-2000s }\end{array}$ & $\begin{array}{c}\text { Period 3 } \\
\text { 21st Century }\end{array}$ \\
\hline Success criteria & $\begin{array}{c}\text { "Iron triangle" } \\
\text { (time, cost, quality) }\end{array}$ & $\begin{array}{c}\text { "Iron triangle" } \\
\text { Client satisfaction } \\
\text { Benefits to organizations } \\
\text { End-user's satisfaction } \\
\text { Benefits to stakeholders } \\
\text { Benefits to project personnel }\end{array}$ & $\begin{array}{c}\text { The strategic objective of client } \\
\text { organizations and business success } \\
\text { End-user's satisfactions Benefits to } \\
\text { stakeholders Benefits of project } \\
\text { personnel and symbolic and rhetoric } \\
\text { evaluation of success and failure }\end{array}$ \\
\hline Success factors & Anecdotic lists & CSF lists and frameworks & $\begin{array}{c}\text { More inclusive CSF framework and } \\
\text { symbolic and rhetoric success factors }\end{array}$ \\
\hline Emphasis & Project management success & Project/Product success & $\begin{array}{c}\text { Project/product, portfolio and } \\
\text { program success, and narratives of } \\
\text { success and failure }\end{array}$ \\
\hline
\end{tabular}

Source: created by authors.

During period 1 (the 1960s-1980s) iron triangle was used as a success criterion while critical success factors were less discussed. In period 2 (the 1980s-2000s), the iron triangle was still significant but the other success criteria emerged [47]. Some of the criteria that emerged in this period are client satisfaction, benefits to an organization, end-user satisfaction, and benefits to stakeholders and project personnel [48]. Additionally, in period 2, the shift from project management success to project success orientation was noticeable [49]. Throughout this period emerged great Pinto and Slevin studies [41]. Though they were not the pioneers in investigating project success [50], Pinto and Slevin methodically focused on 
both project success aspects: (1) measuring success and (2) identifying the critical success factors. Additionally, they developed the Project Implementation Profile (PIP) Scale including 10 critical success factors (CSFs), which allowed project managers to benchmark their project performance concerning the critical factors [51]. Table 2 shows the list of 10 CSF and their definitions.

Table 2. Definitions of 10 critical success factors.

\begin{tabular}{|c|c|}
\hline Critical Success Factor & Definition \\
\hline Project mission & Initial clarity of goals and general directions \\
\hline Top management support & $\begin{array}{c}\text { The willingness of top management to provide the necessary resources and authority/power for } \\
\text { project success }\end{array}$ \\
\hline Project schedule/plans & A detailed specification of the individual action steps required for project implementation \\
\hline Client consultation & Communication, consultation, and active listening to all impacted parties \\
\hline Personnel & Recruitment, selection, and training of the necessary personnel for the project team \\
\hline Technical tasks & $\begin{array}{l}\text { Availability of the required technology and expertise to accomplish the specific technical } \\
\text { action steps }\end{array}$ \\
\hline Client acceptance & The act of 'selling' the final project to its ultimate intended users \\
\hline
\end{tabular}

Monitoring and feedback Timely provision of comprehensive control information at each stage in the implementation process

Communication

The provision of an appropriate network and necessary data to all key actors in the project implementation

Troubleshooting

Ability to handle unexpected crises and deviations from the plan

Source: Pinto and Slevin, 1988.

The PIP scale has been used for years to help organizations estimate the success of their projects. That is the reason authors decided to use exactly this scale for project success assessment. There is more about research assessment in the Methods chapter. To conclude, researchers during the 2000s (Period 3) introduced other context-dependent and project/program/portfolio success criteria and many other critical success factors [52].

\subsection{Stakeholder Relationships}

Infrastructure projects in general tend to have many stakeholders. Thus, managing and getting support from them is extremely important in construction projects, and many authors are convinced that stakeholder management in a construction industry is a focus of the next generation of project management $[34,53,54]$. One of the first definitions of stakeholders was given by Freeman [55]: "any group or individual who can affect or be affected by the achievement of the organization's objectives". Furthermore, Cleland [56] defined the project stakeholders as "individuals or institutions that are either under or beyond project manager's authority, and directly or indirectly get affected by the project's outcome, and have share/stake/interest in the project". Additionally, the Project Management Institute (PMI) [57] reports that stakeholders are "individual, group, or organization who may affect or be affected by, or perceive itself to be affected by a decision, activity, or outcome of a project, who may be actively involved in the project or have interests that may be positively or negatively affected by the performance of completion of the project". Davis [58] demonstrated a comprehensive list of stakeholder subcategories and their frequency in project management literature from 1970 to 2014. Although the stakeholders' definitions point out the project manager and stakeholders, as a different term, Davis emphasizes that project manager is mentioned even 31 times in the literature as a subcategory of stakeholders. It immediately follows the terms project team, client, contractor, user/end-user/consumer, customer, project sponsor, etc. Perhaps the most commonly accepted stakeholders categorization is given in Mazur et al.'s research [12]: (1) internal project stakeholders and (2) external project stakeholders. Internal project stakeholders are 
interpersonal workplace relationships between major project managers and project team members or immediate superiors/supervisors. Otherwise, the external project stakeholders are third-party contractors, the customer, the government, etc.

Stakeholder management involves a lot of attention in project management literature. Some authors point out that stakeholder management is very well represented in the manufacturing industry, while construction has a lack of practical applications in this field [59]. They also emphasize that the absence of stakeholder management is a common cause of project failure in the construction industry. Stakeholder management is important because it provides the project managers support to maximize the project value to the stakeholders [60]. Project value for the stakeholders, often described as stakeholder satisfaction, implies the fulfillment of stakeholders' pre-project expectations [61]. In construction projects, stakeholder satisfaction is used as one of the success measurements, in addition to the traditional determinants of cost, quality, and time [62]. However, in this paper, the stakeholder relationships will be considered to be mediators that interfere in the relationship between emotional intelligence and project success.

\section{Research Model and Hypotheses Development}

The emotional intelligence of project managers and project team members is a significant determinant of project success [21,23,29,30,63]. Recent research of Rezvani [8] illustrates a positive link between EI and project performance in the context of infrastructure projects. That study presents a model with a positive correlation between EI and project performance through adverse relationships with negative conflict types (relationship, teak, and process). Another research piece [64] conducted among 107 Pakistani construction firms shows that construction project managers' emotional intelligence (EI), managerial competencies, and transformational leadership style has a huge positive impact on project success. Rezvani et al. [9] emphasize that emotional intelligence has a positive effect on project success, and that job satisfaction and trust interfere in this relationship. The studies above served as a guideline for developing the main hypothesis of this research:

Hypothesis 1. Construction project managers' emotional intelligence is positively correlated with project success.

Furthermore, particular attention in the literature is given to the effects of emotional intelligence on team development, conflict resolution, leadership, etc. [65-67]. The papers emphasize that emotional intelligence is fundamental for gaining support from team members and stakeholders. Lopes et al. [11] found that emotional intelligence and personality traits increase the level of satisfaction with social relationships. People with a higher score on the Mayer, Salovey, and Caruso Emotional Intelligence Test (MSCEIT), have more positive and less negative interactions with others. Clarke [20] underlines that project managers with high emotional intelligence can negotiate more effectively with project stakeholders. The same attitude is found in Quinn and Wilemon's work [14]; they considered that emotional intelligence improves interpersonal effectiveness and gives project leaders the ability to deal with sponsors and stakeholders. Mazur et al. [12] figured out that the project manager's EI capability leads to better relationships between internal and external stakeholders. Based on the above discussion, the authors propose the following hypothesis:

Hypothesis 2. Construction project manager's emotional intelligence is positively correlated with (a) internal stakeholder relationships and (b) external stakeholder relationships.

Studies also emphasize $[20,68,69]$ that the project manager's relationships with stakeholders such as stakeholder identification, management, and engagement are recognized as crucial project management skills. Beringer [68] in his research examines the influence of stakeholder engagement on project/portfolio success. He proved a huge positive correlation between stakeholder engagement and portfolio success. On the other hand, poor stakeholder management influences project outcomes. Walker [70] identified a tool that 
helps project teams in developing stakeholder engagement strategies. Turner and Zolin [71] developed a set of performance indicators to forecast how various stakeholders will improve success on large projects. Davis [58] investigates which factors project stakeholders perceived as critical for project success. Similar research conducted by Rajablu et al. [69] explains that stakeholder attributes, their understanding, and effective management are identified as the key to project success. Hypothesis 3 is formulated considering the above works.

Hypothesis 3. (a) Internal stakeholder relationships and (b) external stakeholder relationships are positively correlated with project success.

Thus, emotional intelligence helps the project managers to improve relationships with their stakeholders which further leads to project success. Therefore, internal and external stakeholders may play a mediating role in the relationships between emotional intelligence and project success.

Hypothesis 4. Internal and external stakeholder relationships mediate the relationship between emotional intelligence and project success.

Based on the above discussion, this chapter concludes with the conceptual model of the research which will be empirically investigated and explained in later chapters.

\section{Method}

\subsection{Sample and Data Collection Procedure}

The data for this study was collected during 2020, after the outbreak of the global COVID-19 pandemic, using an electronic survey. The survey was distributed to a group of 150 project managers (of different expertise levels) from the 30 most successful companies on the Serbian market. The total of 110 project managers participated in the study which implies the response rate $73.3 \%$. Among the total number of respondents, $46.4 \%$ were male and 53.6\% were female, as given in Table 3. Most of them have Bachelors of Science (48.2\%) and Masters of Science (40.0\%). There are 30.9\% of senior project managers, $36.4 \%$ medial project managers, and $28.2 \%$ of junior project managers. More than half of the participants come from large companies (55.5\%), and most of them had participated in more than 5 projects (5 to 15 projects: $39.1 \%$, and more than 15 projects: $39.1 \%$ ). More than half of the participants $(64.5 \%)$ vouch that their company has a project management office (PMO). The average age of the participants is 37.15 years. They have an average of 12.83 years of work experience, while 6.36 years of experience in project management (PM).

Table 3. Participant characteristics.

\begin{tabular}{|c|c|c|}
\hline Characteristics & $\mathbf{N}$ & $\%$ of $N$ \\
\hline \multicolumn{3}{|l|}{ Sex } \\
\hline Male & 51 & 46.4 \\
\hline Female & 59 & 53.6 \\
\hline \multicolumn{3}{|l|}{ Education } \\
\hline High school & 5 & 4.5 \\
\hline $\mathrm{BSc}$ & 53 & 48.2 \\
\hline MSc & 44 & 40.0 \\
\hline $\mathrm{PhD}$ & 8 & 7.3 \\
\hline Position & & \\
\hline
\end{tabular}


Table 3. Cont.

\begin{tabular}{lcc}
\hline \multicolumn{1}{c}{ Characteristics } & $\mathbf{N}$ & \% of N \\
\hline Senior Project Manager & 34 & 30.9 \\
Junior Project Manager & 31 & 28.2 \\
Medial Project Manager & 40 & 36.4 \\
Scrum Master & 2 & 1.8 \\
Other & 3 & 2.7 \\
\hline Number of employees & & \\
\hline Less than 50 & 20 & 18.2 \\
50-250 employees & 29 & 26.4 \\
More than 250 & 61 & 55.5 \\
\hline Number of projects & & 21.8 \\
\hline Less than 5 & 24 & 39.1 \\
5-15 projects & 43 & 39.1 \\
More than 15 & 43 & \\
\hline PMO in a company & & 64.5 \\
\hline Yes & 71 & 35.5 \\
No & 39 & SD \\
\hline Age & Mean (Years) \\
Work experience & 37.15 & 9.974 \\
\hline Experience in project management & 12.83 & 5.798 \\
\hline
\end{tabular}

\subsection{Measures}

In this research, the authors used validated measures of emotional intelligence, stakeholder relationships, and project success. All the measures asked participants to rate each scale item using a five-point Likert scale, ranging from 1 (strongly disagree) to 5 (strongly agree).

\subsubsection{Independent Variables}

To measure Emotional Intelligence, the Wong and Law scale (WLEIS) is used based on the Mayer and Salovey definition of EI. This scale includes four dimensions:

1. Self-emotions appraisal (SEA) - evaluation and expression of emotion in oneself

2. Others-emotions appraisal (OEA) - evaluation and recognition of emotion in others

3. Use of emotion (UE) - the use of emotion to facilitate thought

4. Regulation of emotion (RE) - managing emotion in oneself

The WLEIS scale of EI was designed for use in management research. According to Mayer et al. [23], a self-emotion appraisal is one's capacity to be self-aware of emotions and to express them precisely. On the other hand, emotional assimilation is the ability to distinguish the different emotions and to identify emotions that affect one's thought process. Understanding emotions involves knowledge about the origin and relation between emotions. Finally, managing emotions involves managing oneself and others' emotions in order to achieve a desirable result and assessing strategies for controlling emotions.

\subsubsection{Dependent Variables}

For the project success measurement, we used Pinto and Slevin's [58] Project Implementation Profile (PIP) scale. More about the PIP scale and 10 critical success factors is explained in the theoretical background. The authors decided to evaluate the following four factors for the purpose of this research. The main reason for selecting these factors relies in fact that they are the most affected by project stakeholder relationships [12,40,41,72-74].

1. Project mission (PMis) — initial clarity of goals and general directions; 
2. Top management support (MS) — the willingness of top management to provide the necessary resources and authority/power for project success;

3. Project communication (PC) - the provision of an appropriate network and necessary data to all key actors in the project implementation;

Trouble-Shooting/Problem Solving (ProbS) - ability to handle unexpected crises and deviations from the plan.

\subsubsection{Mediator Variables}

The mediator variable in the model is stakeholder relationships. It is measured by two separate scales according to Mazur [12]:

1. Internal stakeholder relationships evaluation.

2. External stakeholder relationships evaluation.

Both are a five-point Likert scale, ranging from 1 (strongly disagree) to 5 (strongly agree) and include sub-factors of stakeholder relationships: stakeholder relationship development, stakeholder relationship quality, and stakeholder relationship effectiveness.

\subsubsection{Analysis}

All analyses related to conducted research were made in software packages SPSS Statistics version 27 . The data analysis was undertaken in two different ways using:

- Confirmatory Factor Analysis (CFA);

- $\quad$ Structural Equation Modelling (SEM).

CFA is used for the study constructs, while SEM is used for investigating the relationships among emotional intelligence, stakeholder relationships, and project success.

Both analyses provide answers to the research question raised and could be conducted on the Liker-point data. Namely, the phenomenon of emotional intelligence is difficult to measure and quantify with a single variable. The authors measured them with multiple variables. Generally, the mean values per scale could be used, but in such a way the significant information could have been lost. Therefore, CFA and SEM analysis allowed the creation of latent variables and include all measured variables in the model and analyses.

As all data used in the research is measured on a five-point Likert scale, the authors did not explore the normality of the data.

Regarding the sample size, research indicates that even samples of size between 100 and 150 are sufficient to obtain meaningful results $[75,76]$. On the other hand, if the rule of the thumb 5 observations per variable was taken, the sample would have been undersampled. However, considering the population size, sample size, and obtained meaningful and feasible results, the authors found the sample suitable for the conducted analyses.

\section{Results}

\subsection{Measurement Validation}

To determine the fit of the model, in this conducted research Confirmatory Factor Analysis (CFA)is used. Some of the scales were fitted using the single-factor models (internal stakeholder relationships and external stakeholder relationships), while others were fitted using multiple-factor models (emotional intelligence and project success). The fit indices that are used were the $\chi^{2}$ statistic, the Comparative Fit Index (CFI), the TuckerLewis Index (TLI), the Root Mean Square Error of Approximation (RMSEA) [72,73], and Chronbach's alpha [77,78].

The scales that measured internal stakeholder relationships (ISR) and external stakeholder relationships (ESR) exhibited a slightly lower fit, according to measurement fits given in Table 4. For ISR, RMSEA was 0.161, TLI was 0.737, and CFI is 0.812, while for ESR, RMSEA was 0.130 , TLI was 0.779 , and CFI was 0.842 . However, as shown in Table 3, their Cronbach's alpha exceeds the threshold of 0.7 (for ISR, Alpha $=0.754$, while for ESR, Alpha $=0.836$, which represents a good internal consistency). For bots ISR and ESR, $\chi^{2}$ tests were statistically significant. Moreover, according to Kenny, Kaniskan, and McCoach, 
RMSEA often tends to be higher in models with low degrees of freedom (df), and as for ISR and ESR, exist only at $20 \mathrm{df}$ [79].

Table 4. Confirmatory factor analysis model fit $(\mathrm{N}=110)$.

\begin{tabular}{|c|c|c|c|c|c|c|c|}
\hline Variable & $x^{2}$ & df & $\chi^{2} / \mathrm{df}$ & $p^{1}$ & TLI & CFI & RMSEA \\
\hline $\begin{array}{c}\text { Emotional } \\
\text { intelligence (EI) }\end{array}$ & 173.810 & 98 & 1.774 & $<0.001$ & 0.804 & 0.840 & 0.084 \\
\hline $\begin{array}{l}\text { Internal Stakeholder } \\
\text { Relationships (ISR) } \\
\text { External }\end{array}$ & 76.755 & 20 & 3.838 & $<0.001$ & 0.737 & 0.812 & 0.161 \\
\hline $\begin{array}{c}\text { Stakeholder } \\
\text { Relationships (ESR) }\end{array}$ & 56.972 & 20 & 2.849 & $<0.001$ & 0.779 & 0.842 & 0.130 \\
\hline Project Success (PS) & 277.28 & 164 & 1.691 & $<0.001$ & 0.839 & 0.861 & 0.080 \\
\hline
\end{tabular}

Emotional Intelligence (EI) and Project Success (PS) each comprise four sub-scales, which were elaborated in the previous chapter. They both exhibit a slightly better fit, as shown in Table 4. For EI, RMSEA was 0.084, TLI was 0.804, and CFI is 0.840 , while for ESR, RMSEA was 0.080 , TLI was 0.839 , and CFI was 0.861 . For bots ISR and ESR, $\chi^{2}$ tests were statistically significant.

Since all constructs in this study were measured simultaneously, regardless of the dependent or independent variables, there was a chance that the data were facing the common method bias (CMB) [80,81]. It can be detected through the systematic variance [82] that can boost or diminish a relationship among constructs [83]. The determination of whether a proportion of the observed covariance can be associated with the questionary, single unmeasured latent method factor was controlled through Harman's unrotated single factor test [84]. A single factor was shown to account for $20.481 \%$ of all the variables in the model. Since it is less than $50 \%$, the research construct was shown to be free from significant common method bias effects.

Table 5 shows number of sub-constructs, mean values, standard deviations (SD), Cronbach alphas, and correlation coefficients for all the hypothesized scale measurements. Emotional Intelligence (EI) is comprised of four sub-scales: Self-Emotions Appraisal (SEA), Others-Emotions Appraisal (OEA), Use of Emotion (UE), and Regulation of Emotion (RE). Each of those sub-scales consists out of 4 sub-constructs. For SEA and RE Cronbach alphas are above the threshold of 0.7 , while for OEA and UE it is very close to this threshold. For convergent validity, composite reliability (CR) and average variance extracted (AVE) were additionally calculated for these variables. For OEA, CR was 0.801 and for UE it was 0.8 , which is above the 0.7 threshold, while for OEA, AVE was 0.51 and for UE it was 0.502 , which is above the 0.5 threshold [85]. Project Success (PS) also consists of four sub-scales: Project Mission (PMis), Management Support (MS), Project Communication (PC), and Problem Solving (ProbS). As shown in Table 3, their Cronbach alphas are above the 0.7 threshold.

The correlation coefficients among all the hypothesized variables are also given in Table 5. The significant correlations are flagged in the table. Both the internal stakeholder relationships and external stakeholder relationships are positively and significantly correlated with all the elements of the project success (PMis, MS, PC, and ProbS), by a relationship of medium strength (all above 0.3). This favors the hypotheses H3a and H3b, when observed individually. Regarding the elements of emotional intelligence, OEA and $\mathrm{RE}$ are positive and significant but weakly correlated with internal stakeholder relationships, which partially supports $\mathrm{H} 2 \mathrm{a}$. Further, UE and RE are positively and significant but weakly correlated with external stakeholder relationships, which partially supports $\mathrm{H} 2 \mathrm{~b}$. 
Table 5. Variables' measurement scales, number of sub-constructs, mean, Standard Deviation (SD), Cronbach's alpha, and variables' correlation coefficients.

\begin{tabular}{|c|c|c|c|c|c|c|c|c|c|c|c|c|c|c|}
\hline Variable & Sub-Con. & Mean & SD & Alpha & SEA & OEA & UE & RE & ISR & ESR & PMis & MS & PC & ProbS \\
\hline Self-Emotions Appraisal (SEA) & 4 & 4.27 & 0.508 & 0.715 & - & & & & & & & & & \\
\hline Others-Emotions Appraisal (OEA) & 4 & 4.05 & 0.536 & 0.690 & 0.373 ** & - & & & & & & & & \\
\hline Use of Emotion (UE) & 4 & 4.23 & 0.576 & 0.691 & $0.193 *$ & 0.062 & - & & & & & & & \\
\hline Regulation of Emotion (RE) & 4 & 3.79 & 0.647 & 0.797 & 0.158 & 0.161 & 0.182 & - & & & & & & \\
\hline Internal Stakeholder Relationships (ISR) & 8 & 4.10 & 0.493 & 0.836 & 0.178 & $0.205 *$ & 0.177 & $0.312 * *$ & - & & & & & \\
\hline External Stakeholder Relationships (ESR) & 8 & 4.08 & 0.454 & 0.807 & 0.139 & 0.182 & 0.305 ** & 0.229 * & $0.796 * *$ & - & & & & \\
\hline Project Mission (PMis) & 5 & 4.27 & 0.541 & 0.744 & $0.238 *$ & 0.059 & $0.395^{* *}$ & 0.102 & $0.473^{* *}$ & $0.434^{* *}$ & - & & & \\
\hline Management Support (MS) & 5 & 3.77 & 0.733 & 0.841 & 0.227 * & 0.057 & 0.044 & 0.059 & $0.445^{* *}$ & $0.339 * *$ & $0.490 * *$ & - & & \\
\hline Project Communication (PC) & 5 & 3.81 & 0.637 & 0.779 & 0.121 & 0.071 & $0.291 * *$ & -0.050 & $0.392 * *$ & $0.375^{* *}$ & 0.548 ** & $0.329 * *$ & - & \\
\hline Problem Solving (ProbS) & 5 & 4.11 & 0.631 & 0.757 & $0.212 *$ & 0.154 & $0.365^{* *}$ & 0.114 & $0.408^{* *}$ & $0.425^{* *}$ & $0.631^{* *}$ & $0.473^{* *}$ & $0.595^{* *}$ & - \\
\hline
\end{tabular}


If the elements of emotional intelligence and project success are observed, not all the elements are significantly correlated. SEA is significant and weakly correlated with PMis, MS, and ProbS. UE is significant and moderately correlated with PMis and ProbS, and weakly with PC. OEA and RE are not significantly correlated with the elements of project success. This partially supports H1, observed individually. To further test the research hypotheses, we generated the structural equation model.

\subsection{Structural Equation Modeling}

As mentioned before, the authors included all the hypothesized variables, listed in Table 5, in the initial model, as given in Figure 1. Table 6 presents the results of the initial structural equation model (SEM). The $\chi^{2}$ statistic of the initial model was statistically significant $\left(\chi^{2}=186.657, p<0.001\right)$. Moreover, according to the coefficient of discrimination, the initial model explained $34.5 \%$ of the variability of project mission, $24.9 \%$ of management support, $23.3 \%$ of project communication, and $24.1 \%$ of the variability of problem-solving.

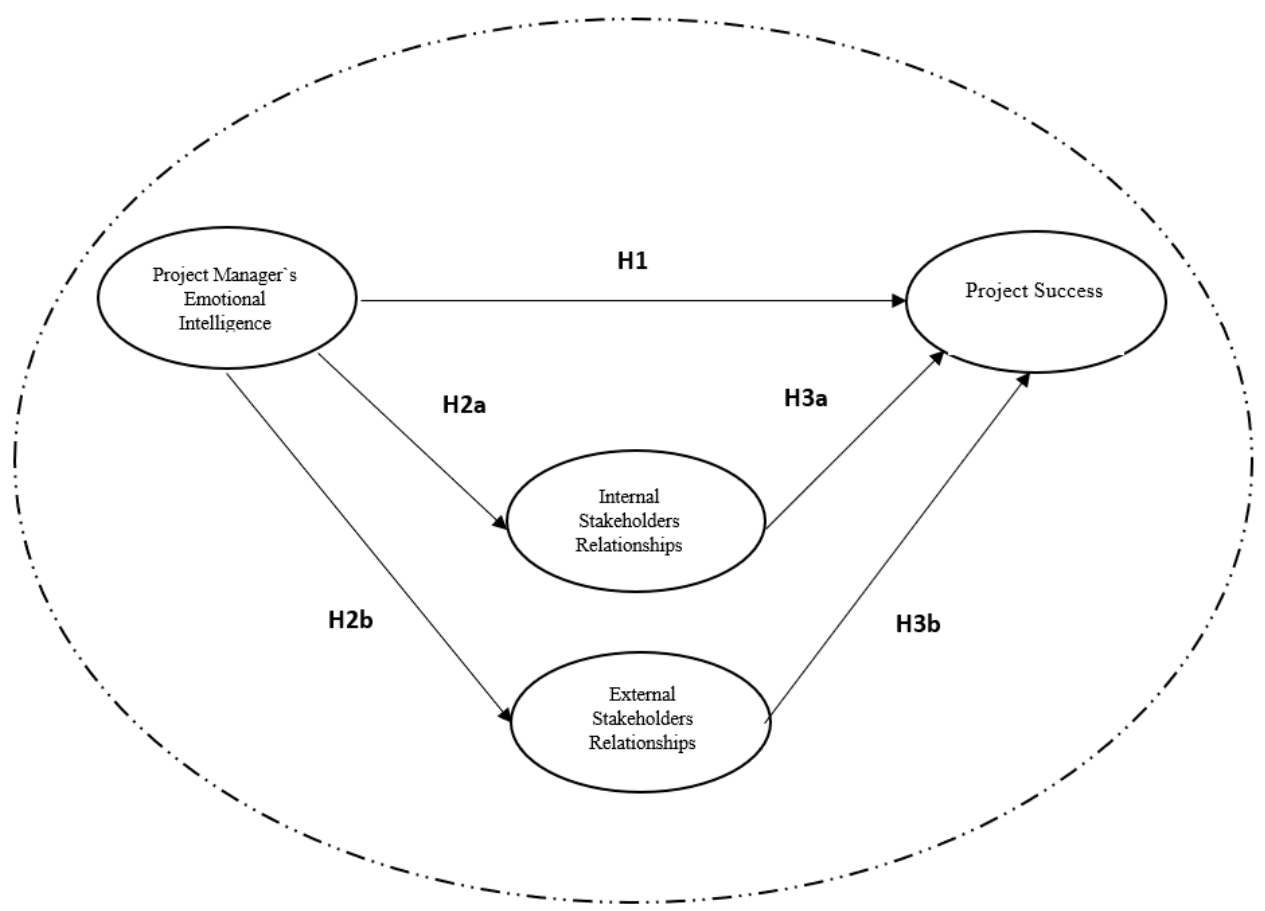

Figure 1. Conceptual model of the study.

Table 6. SEM Initial Model.

\begin{tabular}{ccccccc}
\hline $\begin{array}{c}\text { Independent } \\
\text { Variables }\end{array}$ & $\begin{array}{c}\text { Direction of } \\
\text { Influence }\end{array}$ & $\begin{array}{c}\text { Dependent } \\
\text { Variables }\end{array}$ & $\boldsymbol{\beta}^{\mathbf{1}}$ & S.E. $^{{ }^{2}}$ & C.R. $^{{ }^{3}}$ & $\boldsymbol{p}$ \\
\hline SEA & $\rightarrow$ & ESR & 0.023 & 0.174 & 0.131 & 0.895 \\
RE & $\rightarrow$ & ESR & 0.220 & 0.128 & 1.717 & 0.086 \\
UE & $\rightarrow$ & ESR & 0.418 & 0.144 & 2.903 & 0.004 \\
OEA & $\rightarrow$ & ESR & 0.229 & 0.163 & 1.411 & 0.158 \\
UE & $\rightarrow$ & ISR & 0.185 & 0.157 & 1.179 & 0.238 \\
RE & $\rightarrow$ & ISR & 0.397 & 0.140 & 2.837 & 0.005 \\
SEA & $\rightarrow$ & ISR & 0.130 & 0.190 & 0.687 & 0.492 \\
OEA & $\rightarrow$ & ISR & 0.243 & 0.177 & 1.368 & 0.171 \\
SEA & $\rightarrow$ & PMis & 0.199 & 0.113 & 1.763 & 0.078 \\
SEA & $\rightarrow$ & PC & 0.062 & 0.143 & 0.431 & 0.667 \\
SEA & $\rightarrow$ & ProbS & 0.145 & 0.139 & 1.044 & 0.296 \\
SEA & $\rightarrow$ & MS & 0.370 & 0.166 & 2.228 & 0.026 \\
OEA & $\rightarrow$ & PMis & -0.114 & 0.107 & -1.064 & 0.287 \\
OEA & $\rightarrow$ & MS & -0.165 & 0.157 & -1.050 & 0.294 \\
\hline
\end{tabular}


Table 6. Cont.

\begin{tabular}{ccccccc}
\hline $\begin{array}{c}\text { Independent } \\
\text { Variables }\end{array}$ & $\begin{array}{c}\text { Direction of } \\
\text { Influence }\end{array}$ & $\begin{array}{c}\text { Dependent } \\
\text { Variables }\end{array}$ & $\boldsymbol{\beta}^{\mathbf{1}}$ & S.E. $^{\mathbf{2}}$ & C.R. $^{\mathbf{3}}$ & $\boldsymbol{p}$ \\
\hline OEA & $\rightarrow$ & PC & -0.012 & 0.136 & -0.088 & 0.930 \\
OEA & $\rightarrow$ & ProbS & 0.054 & 0.132 & 0.406 & 0.685 \\
UE & $\rightarrow$ & PMis & 0.362 & 0.098 & 3.716 & $<0.001$ \\
UE & $\rightarrow$ & MS & -0.083 & 0.143 & -0.580 & 0.562 \\
UE & $\rightarrow$ & ProbS & 0.368 & 0.120 & 3.062 & 0.002 \\
UE & $\rightarrow$ & PC & 0.337 & 0.123 & 2.735 & 0.006 \\
RE & $\rightarrow$ & PMis & -0.106 & 0.087 & -1.209 & 0.227 \\
RE & $\rightarrow$ & MS & -0.133 & 0.128 & -1.039 & 0.299 \\
RE & $\rightarrow$ & ProbS & -0.078 & 0.107 & -0.728 & 0.467 \\
RE & $\rightarrow$ & PC & -0.280 & 0.110 & -2.537 & 0.011 \\
ESR & $\rightarrow$ & ProbS & 0.130 & 0.076 & 1.695 & 0.090 \\
ESR & $\rightarrow$ & PMis & 0.015 & 0.062 & 0.238 & 0.812 \\
ISR & $\rightarrow$ & ProbS & 0.190 & 0.070 & 2.703 & 0.007 \\
ISR & $\rightarrow$ & PC & 0.302 & 0.072 & 4.198 & $<0.001$ \\
ISR & $\rightarrow$ & MS & 0.446 & 0.084 & 5.337 & $<0.001$ \\
ISR & $\rightarrow$ & PMis & 0.292 & 0.057 & 5.126 & $<0.001$ \\
ESR & $\rightarrow$ & PC & 0.044 & 0.079 & 0.565 & 0.572 \\
ESR & $\rightarrow$ & MS & -0.017 & 0.091 & -0.183 & 0.854 \\
\hline
\end{tabular}

${ }^{1} \beta=$ regression weights; ${ }^{2}$ S.E $=$ standardized Error; ${ }^{3}$ C.R. $=$ critical ratio.

However, not all the coefficients in the model were significant. To reduce the complexity of the model, the non-significant pathways of the initial SEM were dispersed. The pathways where regression coefficients were significant at the 0.1 level of significance were kept. The authors decided to increase the significance threshold to 0.1 (instead of popular 0.05 ) because they aimed at capturing as many relationships as possible between the observed factors. Increasing the significance threshold allowed authors to additionally obtain conclusions on hypothesis $\mathrm{H} 1, \mathrm{H} 2 \mathrm{a}$, and $\mathrm{H} 3 \mathrm{~b}$. The final model is presented in Figure 2 and results are given in Table 7.

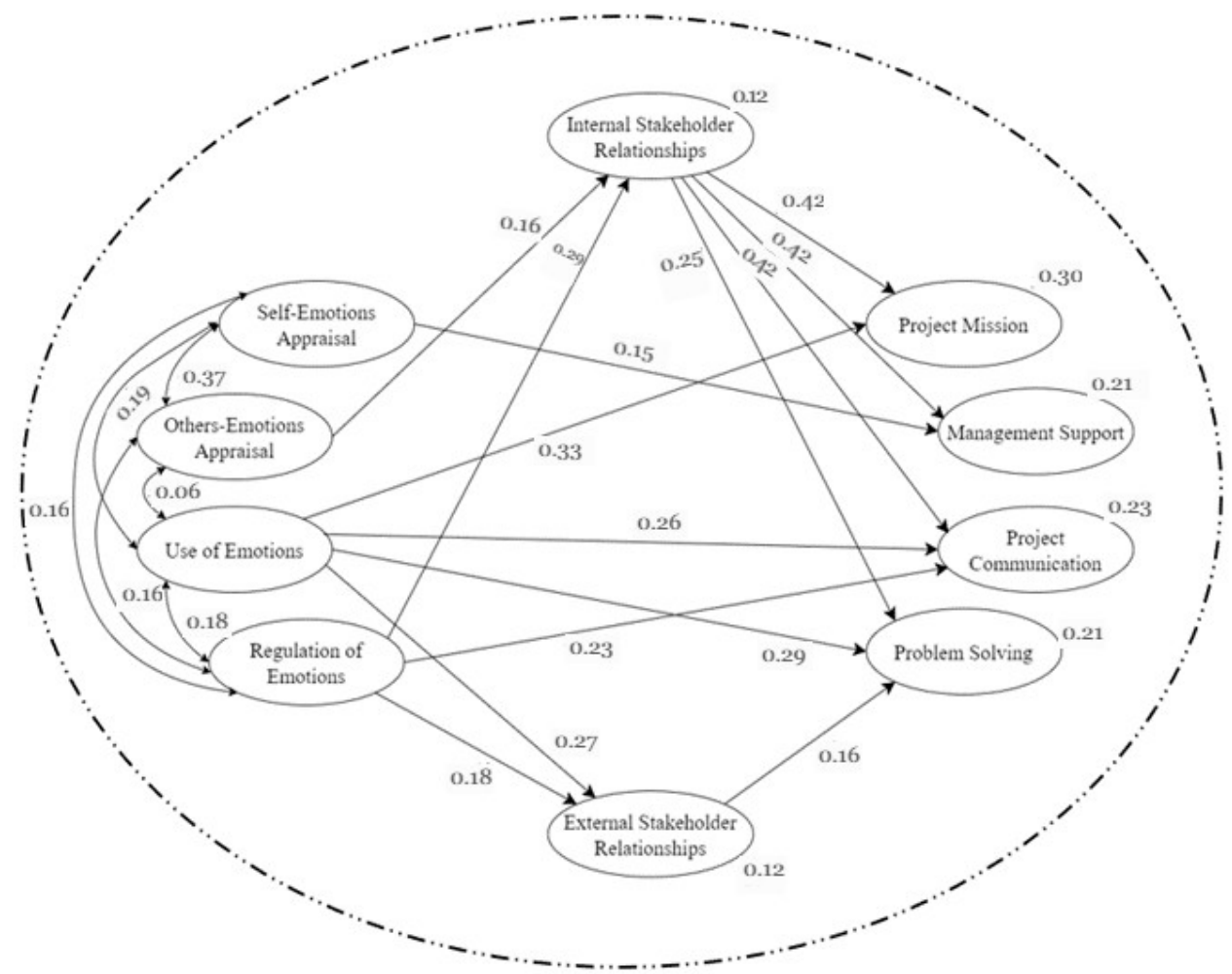

Figure 2. Significant standardized pathways for the SEM final model. 
Table 7. SEM final model.

\begin{tabular}{cccccccc}
\hline $\begin{array}{c}\text { Independent } \\
\text { Variables }\end{array}$ & $\begin{array}{c}\text { Direction of } \\
\text { Influence }\end{array}$ & $\begin{array}{c}\text { Dependent } \\
\text { Variables }\end{array}$ & $\boldsymbol{\beta}^{\mathbf{1}}$ & S.E. $^{\mathbf{2}}$ & C.R. $^{\mathbf{3}}$ & $\boldsymbol{p}$ & Finding \\
\hline OEA & $\rightarrow$ & ISR & 0.293 & 0.167 & 1.754 & 0.079 & H2a Partially Supported \\
RE & $\rightarrow$ & ISR & 0.436 & 0.139 & 3.146 & 0.002 & H2a Partially Supported \\
RE & $\rightarrow$ & ESR & 0.252 & 0.128 & 1.971 & 0.049 & H2b Partially Supported \\
UE & $\rightarrow$ & ESR & 0.429 & 0.143 & 2.989 & 0.003 & H2b Partially Supported \\
SEA & $\rightarrow$ & MS & 0.276 & 0.153 & 1.796 & 0.073 & H1 Mainly Supported \\
UE & $\rightarrow$ & PMis & 0.377 & 0.093 & 4.073 & $<0.001$ & H1 Mainly Supported \\
UE & $\rightarrow$ & PC & 0.358 & 0.116 & 3.071 & 0.002 & H1 Mainly Supported \\
UE & $\rightarrow$ & ProbS & 0.379 & 0.118 & 3.203 & 0.001 & H1 Mainly Supported \\
RE & $\rightarrow$ & PC & -0.279 & 0.109 & -2.563 & 0.010 & H1 Mainly Supported \\
ISR & $\rightarrow$ & PMis & 0.285 & 0.054 & 5.273 & $<0.001$ & H3a Supported \\
ISR & $\rightarrow$ & MS & 0.388 & 0.079 & 4.913 & $<0.001$ & H3a Supported \\
ISR & $\rightarrow$ & PC & 0.337 & 0.070 & 4.784 & $<0.001$ & H3a Supported \\
ISR & $\rightarrow$ & ProbS & 0.191 & 0.066 & 2.900 & 0.004 & H3a Supported \\
ESR & $\rightarrow$ & ProbS & 0.130 & 0.075 & 1.735 & 0.083 & H3b Partially Supported \\
\hline
\end{tabular}

${ }^{1} \beta=$ regression weights; ${ }^{2}$ S.E $=$ standardized error; ${ }^{3}$ C.R. $=$ critical ratio.

As can be seen from Table 7, in the SEM final model of elements of emotional intelligence, self-emotions appraisals were related solely to top management support, from all the elements of project success. The use of emotions was related to the project mission, project communication, and problem-solving, while regulation of emotions was related solely to project communication. These findings mainly support hypothesis H1.

As for the relationship between emotional intelligence and project success, othersemotions appraisals were related to internal stakeholder relationships, regulation of emotions with both internal and external stakeholder relationships and use of emotions with external stakeholder relationships. The self-emotions appraisal was not related to any element of project success. These findings partially support the hypotheses $\mathrm{H} 2 \mathrm{a}$ and $\mathrm{H} 2 \mathrm{~b}$.

Internal stakeholder relationships were significantly and positively related to all the elements of the project success (PMis, MS, PC, and ProbS), which completely supports H3a. External stakeholder relationships were related only to problem-solving, which partially supports the hypothesis $\mathrm{H} 3 \mathrm{~b}$.

Table 8 presents the statistics of the SEM final model. The $\chi^{2}$ statistic was statistically significant $\left(\chi^{2}=201.225, \mathrm{df}=25, p<0.001\right)$. The RMSEA for this model is 0.254 , but as noted before according to Kenny, Kaniskan, and McCoach [79], it is common to be higher for low degrees of freedom. The SEM final model explained $30.2 \%$ of the variability of project mission, $21.3 \%$ of management support, $23.2 \%$ of project communication, and $20.9 \%$ of the variability of problem-solving.

Table 8. SEM final model statistics.

\begin{tabular}{cc}
\hline Dependent Variables & $\mathbf{R}^{2}$ \\
\hline ISR & 0.122 \\
ESR & 0.124 \\
PMis & 0.302 \\
MS & 0.213 \\
PC & 0.232 \\
ProbS & 0.209 \\
\hline Model fits & \\
\hline$\chi^{2}$ & 201.225 \\
df & 25 \\
$\chi^{2} /$ df & 8.049 \\
$p$ & $<0.001$ \\
RMSEA & 0.254 \\
\hline
\end{tabular}




\section{Discussion}

As well as numerous assertions $[21,23,29,30,63]$, the findings of this study show that project managers' emotional intelligence is an important determinant of project success also in the context of the construction industry. Infrastructure projects tend to have many stakeholders and obtaining support from them is a crucial responsibility for construction project managers $[34,53,54]$. Good relationships with stakeholders have always been some of the most challenging and most important skills of project managers, and nowadays in the digital era are significantly more than ever. The results demonstrate that project managers with higher emotional intelligence have better relationships with internal and external stakeholders and, consequently, better relationships with stakeholders lead to a higher project. This confirmed that Mazur's [12] claim is also valid in the construction industry and that internal and external stakeholder relationships play a crucial mediator role in the relationships between construction project managers' emotional intelligence and project success. Furthermore, this study demonstrates that some of the four EI components: Self-Emotions Appraisal (SEA), Others-Emotions Appraisal (OEA), Use of Emotions (UE), and Regulation of Emotions (RE) have a different impact on the observed dependent variables, and those correlations are explained below.

In the previous section, Self-Emotions Appraisal has a great impact, related solely to top management support, one of four components of project success. The use of emotions was related to project mission, project communication, and problem-solving, while regulation of emotions was related solely to project communication. These findings mainly support hypothesis $\mathrm{H} 1$, that construction project managers' emotional intelligence is positively correlated with project success. Furthermore, OEA and RE have a significant impact on relations with internal stakeholders and UE and RE have a positive effect on relations with external stakeholders, which partially confirms the hypothesis $\mathrm{H} 2$ that construction project managers' emotional intelligence is positively correlated with (a) internal stakeholder relationships and (b) external stakeholder relationships.

According to Loosemore [59], stakeholder management provides the project managers support to maximize the value to the stakeholders, and the absence of stakeholder management is a common cause of project failure in the construction industry. This research confirmed that construction project managers' relationships with internal stakeholders have a positive impact on project success and that those relationships were significantly and positively correlated with each observed component of project success (Project Mission, Management Support, Project Communication, and Problem Solving). It means that high-quality relations with internal stakeholders contribute to a clearer mission of the project, greater support from top management, improved communication, and more efficient problem-solving. Accordingly, hypothesis H3a that Internal stakeholder relationships are positively correlated with project success was completely confirmed. On the other hand, relations with external stakeholders significantly affect only one component of project success (Problem Solving) thus, hypothesis H3b External stakeholder relationships are positively correlated with project success is only partially confirmed.

\section{Conclusions}

This research confirmed many claims that emotional intelligence significantly influences project success in the construction industry and that internal and external stakeholders' relationships play crucial mediator role among them. However, authors acknowledge four issues of this study that could be opportunities for future research. Firstly, the results may be limited because the data were collected in 30 organizations from one market: Serbia. In this case, it might be useful to see if the findings can be recreated in other national settings. Another limitation is that the research includes only two mediators of the EI-project success relationship: internal and external stakeholder relationships, and the authors suggest that future research considers other mediators (such as job satisfaction, trust, leadership style, etc.). The third limitation is that conducted research was a self-assessment of emotional intelligence that might be subjective and less relevant than psychological assessment. Finally, 
the study is focused only on the one industry: construction. In this regard, researchers in the future have the opportunity to examine this relationship in other industries.

Notwithstanding these limitations, the authors believe that this study contributes to the construction project management literature by integrating emotional intelligence, stakeholder relationships, and project success theory, and provides a new model based on empirically confirmed results. On the other hand, this study shows that construction project managers with a higher level of emotional intelligence can develop and maintain high-quality relationships with both internal and external stakeholders, which leads to successful project realization. Therefore, this paper might be useful as a guidebook for construction organizations, top managers, and human resource managers when selecting new project management practitioners.

Author Contributions: Conceptualization, A.M. and V.O.; methodology, M.D.; software, M.D.; validation, M.D.; formal analysis, M.D.; investigation, A.M. and T.S.; data curation, A.M. and T.S.; writing—original draft preparation, A.M.; writing—review and editing, A.M., M.T. and V.O.; supervision, M.T. and V.O.; project administration, T.S. All authors have read and agreed to the published version of the manuscript.

Funding: This research received no external funding.

Institutional Review Board Statement: Ethical review and approval were waived for this study, due to all the surveys were conducted anonymously and only collected non-confidential data.

Informed Consent Statement: Informed consent was obtained from all subjects involved in the study.

Data Availability Statement: The data presented in this study are available on request from the corresponding author.

Conflicts of Interest: The authors declare no conflict of interest.

\section{References}

1. Cheng, M.I.; Dainty, A.R.J.; Moore, D.R. What makes a good project manager? Hum. Resour. Manag. J. 2005, 15, 25-37. [CrossRef]

2. Edum-Fotwe, F.T.; McCaffer, R. Developing project management competency: Perspectives from the construction industry. Int. J. Proj. Manag. 2000, 18, 111-124. [CrossRef]

3. Khlaifat, D.M.; Alyagoub, R.E.; Sweis, R.J.; Sweis, G.J. Factors leading to construction projects' failure in Jordon. Int. J. Constr. Manag. 2017, 19, 65-78. [CrossRef]

4. Toor, S.U.R.; Ogunlana, S. Problems causing delays in major construction projects in Thailand. Constr. Manag. Econ. 2008, 26, 395-408. [CrossRef]

5. Meng, X.; Boyd, P. The role of the project manager in relationship management. Int. J. Proj. Manag. 2017, 35, 717-728. [CrossRef]

6. Butler, C.J.; Chinowsky, P.S. Emotional Intelligence and Leadership Behavior in Construction Executives. J. Manag. Eng. 2006, 22, 119-125. [CrossRef]

7. Love, P.; Edwards, D.; Wood, E. Loosening the Gordian knot: The role of emotional intelligence in construction. Eng. Constr. Archit. Manag. 2011, 18, 50-65. [CrossRef]

8. Rezvani, A.; Ashkanasy, N.; Khosravi, P. Key Attitudes: Unlocking the Relationships between Emotional Intelligence and Performance in Construction Projects. J. Constr. Eng. Manag. 2020, 146, 04020025. [CrossRef]

9. Rezvani, A.; Chang, A.; Wiewiora, A.; Ashkanasy, N.M.; Jordan, P.J.; Zolin, R. Manager emotional intelligence and project success: The mediating role of job satisfaction and trust. Int. J. Proj. Manag. 2016, 34, 1112-1122. [CrossRef]

10. Zhang, L.; Cao, T.; Wang, Y. The mediation role of leadership styles in integrated project collaboration: An emotional intelligence perspective. Int. J. Proj. Manag. 2018, 36, 317-330. [CrossRef]

11. Lopes, P.N.; Salovey, P.; Straus, R. Emotional intelligence, personality, and the perceived quality of social relationships. Pers. Individ. Dif. 2003, 35, 641-658. [CrossRef]

12. Mazur, A.; Pisarski, A.; Chang, A.; Ashkanasy, N.M. Rating defence major project success: The role of personal attributes and stakeholder relationships. Int. J. Proj. Manag. 2014, 32, 944-957. [CrossRef]

13. Obradovic, V.; Jovanovic, P.; Petrovic, D.; Mihic, M.; Mitrovic, Z. Project Managers' Emotional Intelligence-A Ticket to Success. Procedia-Soc. Behav. Sci. 2013, 74, 274-284. [CrossRef]

14. Quinn, J.F.; Wilemon, D. Emotional intelligence as a facilitator of project leader effectiveness. In Proceedings of the PICMET: Portland International Center for Management of Engineering and Technology, Portland, OR, USA, 2-6 August 2009; pp. $1267-1275$.

15. Rosete, D.; Ciarrochi, J. Emotional intelligence and its relationship to workplace performance outcomes of leadership effectiveness. Leadersh. Organ. Dev. J. 2005, 26, 388-399. [CrossRef] 
16. Salovey, P.; Mayer, J.D. Emotional Intelligence. Imagin. Cogn. Pers. 1990, 9, 185-211. [CrossRef]

17. Salovey, P.; Sluyter, D.J. Emotional Development and Emotional Intelligence: Educational Implications; Basic Books: New York, NY, USA, 1997.

18. Mayer, J.D.; Caruso, D.R.; Salovey, P. The Ability Model of Emotional Intelligence: Principles and Updates. Emot. Rev. 2016, 8, 290-300. [CrossRef]

19. Goleman, D. Working with Emotional Intelligence; Bantam Books: New York, NY, USA, 1998; ISBN 9780553104622.

20. Clarke, N. Emotional intelligence and learning in teams. J. Work. Learn. 2010, 22, 125-145. [CrossRef]

21. Joseph, D.; Newman, D. Emotional intelligence: An integrative meta-analysis and cascading model. J. Appl. Psychol. 2010, 95, 54-78. [CrossRef]

22. Müller, R.; Turner, R. Leadership competency profiles of successful project managers. Int. J. Proj. Manag. 2010, 28, 437-448. [CrossRef]

23. Mayer, J.D.; Salovey, P.; Caruso, D.R. Emotional intelligence: Theory, findings, and implications. Psychol. Inq. 2004, 15, 197-215. [CrossRef]

24. Emmerling, R.J.; Goleman, D. Emotional intelligence: Issues and common misunderstandings. Issues Recent Dev. Emot. Intell. 2003, 1, 1-32.

25. Cherniss, C.; Goleman, D.; Emmerling, R.; Cowan, K.; Adler, M. Bringing Emotional Intelligence to the Workplace A Technical Report Issued by the Consortium For Research on Emotional Intelligence in Organizations; EI Consortium-Emotional Intelligence Consortium: MI, USA, 1998; Available online: www.EIConsortium.org (accessed on 10 September 2021).

26. Boyatzis, R.E.; Van Oosten, E. International Executive Development Programmes; Kogan Page Publishers: London, UK, 2002.

27. Barling, J.; Slater, F.; Kevin Kelloway, E. Transformational leadership and emotional intelligence: An exploratory study. Leadersh. Organ. Dev. J. 2000, 21, 157-161. [CrossRef]

28. Jordan, P.J.; Ashkanasy, N.M.; Härtel, C.E.J.; Hooper, G.S. Workgroup emotional intelligence. Scale development and relationship to team process effectiveness and goal focus. Hum. Resour. Manag. Rev. 2002, 12, 195-214. [CrossRef]

29. Sunindijo, R.Y.; Hadikusumo, B.H.; Ogunlana, S. Emotional Intelligence and Leadership Styles in Construction Project Management. J. Manag. Eng. 2007, 23, 166-170. [CrossRef]

30. Wu, G.; Zhao, X.; Zuo, J. Relationship between Project's Added Value and the Trust-Conflict Interaction among Project Teams. J. Manag. Eng. 2017, 33, 04017011. [CrossRef]

31. Fisher, E. What practitioners consider to be the skills and behaviours of an effective people project manager. Int. J. Proj. Manag. 2011, 29, 994-1002. [CrossRef]

32. Doan, T.T.T.; Nguyen, L.C.T.; Nguyen, T.D.N. Emotional intelligence and project success: The roles of transformational leadership and organizational commitment. J. Asian Financ. Econ. Bus. 2020, 7, 223-233. [CrossRef]

33. Lima, L.F.; Quevedo-Silva, F. Emotional intelligence and success of project management: The mediating effect of interpersonal skills. Int. J. Proj. Organ. Manag. 2020, 12, 54-73. [CrossRef]

34. Molwus, J.J.; Erdogan, B.; Ogunlana, S. Using structural equation modelling (SEM) to understand the relationships among critical success factors (CSFs) for stakeholder management in construction. Eng. Constr. Archit. Manag. 2017, 24, 426-450. [CrossRef]

35. Müller, R.; Jugdev, K. Critical success factors in projects: Pinto, Slevin, and Prescott-the elucidation of project success. Int. J. Manag. Proj. Bus. 2012, 5, 757-775. [CrossRef]

36. Soderlund, J. Managing complex development projects: Arenas, knowledge processes and time. R D Manag. 2002, 32, 419-430. [CrossRef]

37. Joslin, R.; Müller, R. The impact of project methodologies on project success in different project environments. Int. J. Manag. Proj. Bus. 2016, 9, 364-388. [CrossRef]

38. Todorović, M.L.; Petrović, D.T.; Mihić, M.M.; Obradović, V.L.; Bushuyev, S.D. Project success analysis framework: A knowledgebased approach in project management. Int. J. Proj. Manag. 2015, 33, 772-783. [CrossRef]

39. Serrador, P.; Turner, R. The relationship between project success and project efficiency. Proj. Manag. J. 2015, 46, 30-39. [CrossRef]

40. Ika, L.A. Project Success as a Topic in Project Management Journals. Proj. Manag. J. 2009, 40, 6-19. [CrossRef]

41. Pinto, J.K.; Slevin, D.P. Critical factors in successful project implementation. IEEE Trans. Eng. Manag. 1987, 34, 22-27. [CrossRef]

42. Morris, P.W.G.; Hough, G.H. The Anatomy of Major Projects: A Study of the Reality of Project Management; Wiley: Hoboken, NJ, USA, 1987; ISBN 0471915513.

43. Turner, J.R.; Müller, R. The Project Manager's Leadership Style as a Success Factor on Projects: A Literature Review. Proj. Manag. J. 2005, 36, 49-61. [CrossRef]

44. Wateridge, J. How can IS/IT projects be measured for success? Int. J. Proj. Manag. 1998, 16, 59-63. [CrossRef]

45. Oxford Dictionary of English, 3rd ed.; Oxford University Press: Oxford, UK, 2010.

46. Munns, A.K.; Bjeirmi, B.F. The role of project management in achieving project success. Int. J. Proj. Manag. 1996, $14,81-87$. [CrossRef]

47. Bannerman, P.L. Defining Project Success: A Multilevel Framework; 2008. Available online: https://www.researchgate.net/ publication/242331546_Defining_Project_Success_A_Multi-Level_Framework (accessed on 10 September 2021).

48. Atkinson, R. Project management: Cost, time and quality, two best guesses and a phenomenon, its time to accept other success criteria. Int. J. Proj. Manag. 1999, 17, 337-342. [CrossRef]

49. Baccarini, D. The Logical Framework Method for Defining Project Success. Proj. Manag. J. 1999, 30, 25-32. [CrossRef] 
50. Boynton, A.C.; Zmud, R.W. An Assessment of Critical Success Factors; Sloan Management Review (Pre-1986): Boston, MA, USA, 1984; Volume 25, p. 17.

51. Pinto, J.; Slevin, D. Project Success: Definitions and Measurement Techniques; Project Management Journal: Austin, TX, USA, 1988.

52. Chatzoglou, P.; Fragidis, L.; Chatzoudes, D. Critical Success Factors for ERP Implementation in SMEs; IEEE: Piscataway, NJ, USA, 2016. [CrossRef]

53. Srinivasan, N.P.; Dhivya, S. An empirical study on stakeholder management in construction projects. Proc. Mater. Today 2020, 21, 60-62. [CrossRef]

54. Oppong, G.D.; Chan, A.P.C.; Dansoh, A. A review of stakeholder management performance attributes in construction projects. Int. J. Proj. Manag. 2017, 35, 1037-1051. [CrossRef]

55. Freeman, R. Strategic Management: A Stakeholder Approach; Pitman: Boston, MA, USA, 1984.

56. Cleland, D. A Strategy for Ongoing Project Evaluation; Project Management Institute Inc.: Newtown Square, PA, USA, 1985.

57. PMI. PMBOK Guide, 6th ed.; Project Management Institute Inc.: Newtown Square, PA, USA, 2017; ISBN 9781628253900.

58. Davis, K. Different stakeholder groups and their perceptions of project success. Int. J. Proj. Manag. 2014, 32, 189-201. [CrossRef]

59. Loosemore, M. Managing project risks. In The Management of Complex Projects: A Relationship Approach; Pryke, S., Smyth, H., Eds.; WileyBlackwell: Chichester, UK, 2006.

60. Cleland, D.I. Project Management; McGraw-Hill Education: New York, NY, USA, 2007.

61. Li, T.H.Y.; Ng, S.T.; Skitmore, M. Evaluating stakeholder satisfaction during public participation in major infrastructure and construction projects: A fuzzy approach. Autom. Constr. 2013, 29, 123-135. [CrossRef]

62. Davis, K. An empirical investigation into different stakeholder groups perception of project success. Int. J. Proj. Manag. 2017, 35, 604-617. [CrossRef]

63. Müller, R.; Turner, R. The Influence of Project Managers on Project Success Criteria and Project Success by Type of Project. Eur. Manag. J. 2007, 25, 298-309. [CrossRef]

64. Maqbool, R.; Sudong, Y.; Manzoor, N.; Rashid, Y. The Impact of Emotional Intelligence, Project Managers' Competencies, and Transformational Leadership on Project Success: An Empirical Perspective. Proj. Manag. J. 2017, 48, 58-75. [CrossRef]

65. Feyerherm, A.E.; Rice, C.L. Emotional intelligence and team performance: The good, the bad and the ugly. Int. J. Organ. Anal. 2002, 10, 343-362. [CrossRef]

66. Koman, E.S.; Wolff, S.B. Emotional intelligence competencies in the team and team leader: A multi-level examination of the impact of emotional intelligence on team performance. J. Manag. Dev. 2008, 27, 55-75. [CrossRef]

67. Lee, C.; Wong, C.S. The effect of team emotional intelligence on team process and effectiveness. J. Manag. Organ. 2019, 25, 844-859. [CrossRef]

68. Beringer, C.; Jonas, D.; Kock, A. Behavior of internal stakeholders in project portfolio management and its impact on success. Int. J. Proj. Manag. 2013, 31, 830-846. [CrossRef]

69. Rajablu, M.; Marthandan, G.; Fadzilah, W.; Yusoff, W. Managing for Stakeholders: The Role of Stakeholder-Based Management in Project Success. Asian Soc. Sci. 2015, 11. [CrossRef]

70. Walker, D.H.T.; Bourne, L.M.; Shelley, A. Influence, stakeholder mapping and visualization. Constr. Manag. Econ. 2008, 26, 645-658. [CrossRef]

71. Turner, R.; Zolin, R. Forecasting success on large projects: Developing reliable scales to predict multiple perspectives by multiple stakeholders over multiple time frames. Proj. Manag. J. 2012, 43, 87-99. [CrossRef]

72. Browne, M.W.; Cudeck, R. Alternative Ways of Assessing Model Fit. Sociol. Methods Res. 1992, 21, 230-258. [CrossRef]

73. Steiger, J.H. Notes on the Steiger-Lind (1980) Handout. Struct. Equ. Model. A Multidiscip. J. 2016, 23, 777-781. [CrossRef]

74. Liu, T.-C.; Chen, Y.-J. Strategy orientation, product innovativeness, and new product performance. J. Manag. Organ. 2015, 21, 2-16. [CrossRef]

75. Tinsley, H.E.; Tinsley, D.J. Uses of factor analysis in counseling psychology research. J. Couns. Psychol. 1987, 34, 414-424. [CrossRef]

76. Tabachnick, B.; Fidell, L. Using Multivariate Statistics, 7th ed.; Pearson Education Inc.: New York. NY, USA, 2019.

77. DeVellis, R.F. Scale Development: Theory and Applications (Applied Social Research Methods), 3rd ed.; SAGE Publications, Inc.: Sauzend Oaks, CA, USA, 2011.

78. Kline, P. Handbook of Psychological Testing; Routledge: London, UK, 2013; ISBN 9781315812274.

79. Kenny, D.A.; Kaniskan, B.; McCoach, D.B. The Performance of RMSEA in Models With Small Degrees of Freedom. Sociol. Methods Res. 2015, 44, 486-507. [CrossRef]

80. Podsakoff, P.M.; MacKenzie, S.B.; Lee, J.-Y.; Podsakoff, N.P. Common method biases in behavioral research: A critical review of the literature and recommended remedies. J. Appl. Psychol. 2003, 88, 879-903. [CrossRef] [PubMed]

81. Podsakoff, P.M.; MacKenzie, S.B.; Podsakoff, N.P. Sources of Method Bias in Social Science Research and Recommendations on How to Control It. Annu. Rev. Psychol. 2012, 63, 539-569. [CrossRef]

82. Bagozzi, R.P.; Yi, Y. Assessing method variance in multitrait-multimethod matrices: The case of self-reported affect and perceptions at work. J. Appl. Psychol. 1990, 75, 547-560. [CrossRef]

83. Doty, D.H.; Glick, W.H. Common Methods Bias: Does Common Methods Variance Really Bias Results? Organ. Res. Methods 1998, 1,374-406. [CrossRef] 
84. Harman, H.H. Modern Factor Analysis; University of Chicago Press: Chicago, IL, USA, 1976.

85. Fornell, C.; Larcker, D.F. Evaluating Structural Equation Models with Unobservable Variables and Measurement Error. J. Mark. Res. 1981, 18, 39. [CrossRef] 